\title{
Simultaneous Sensitive Detection of Lead(II), Mercury(II) and Silver Ions Using a New Nucleic Acid-Based Fluorescence Sensor
}

\author{
Yuan Deng, ${ }^{1}$ Yinran Chen ${ }^{2}$ and Xiaodong Zhou ${ }^{2, *}$ \\ ${ }^{1}$ Institute of Scientific Research \& Development, Wuhan University, Wuhan 430072, PR China. \\ ${ }^{2}$ College of Chemistry and Molecular Sciences, Wuhan University, Wuhan 430072, PR China. \\ * Corresponding author: E-mail: Email: zhouxd@whu.edu.cn \\ Phone: +8602768752439 fax: +8602768752136
}

Received: 07-06-2017

\begin{abstract}
A new nucleic acid-based fluorescence sensor is reported for simultaneous detection of $\mathrm{Pb}^{2+}, \mathrm{Ag}^{+}$, and $\mathrm{Hg}^{2+}$ based on the specific catalytic activity of $\mathrm{Pb}^{2+}$ for a particular DNAzyme, specific regulation of $\mathrm{Ag}^{+}$on "C- $\mathrm{Ag}^{+}-\mathrm{C}$ " complex, and stable complex formed by $\mathrm{Hg}^{2+}$ and rhodamine B isothiocyanate (RBITC). Three fluorescence dyes, aminomethylcoumarin acetic acid (AMCA), 5-carboxyfluorescein (FAM), and RBITC, were modified on the probes and served as fluorescent donors. Upon DNA interaction with these metal ions and AuNP fluorescence quenching effect on the fluorescence dyes, the fluorescence recovery of RBITC and the fluorescence quenching of AMCA and FAM were monitored to detect $\mathrm{Hg}^{2+}$, $\mathrm{Pb}^{2+}$, and $\mathrm{Ag}^{+}$, separately, without the need of using any masking reagents. This sensor exhibited high sensitivity and selectivity. The limit of detection (LOD) is $0.48 \mathrm{nM}$ for $\mathrm{Pb}^{2+}, 0.23 \mathrm{nM}^{2} \mathrm{Ag}^{+}$, and $0.17 \mathrm{nM}$ for $\mathrm{Hg}^{2+}$. Finally, this sensor was successfully applied for simultaneous detection of $\mathrm{Pb}^{2+}, \mathrm{Ag}^{+}$, and $\mathrm{Hg}^{2+}$ in real sample.
\end{abstract}

Keywords: Fluorescent sensor; Au nanoparticles (AuNPs); DNAzyme; simultaneous detection; metal ions

\section{Introduction}

With the ever increasing pollution from modern industry, heavy metal contaminants have posed severe adverse effects on human health and ecosystems due to their high and persistent toxicities. ${ }^{1,2}$ Therefore, it is quite necessary and urgent to rapidly and accurately detect these metal ions. Traditional methods, such as atomic absorption spectrometry (AAS), ${ }^{3}$ inductively coupled plasma mass spectrometry (ICP-MS), ${ }^{4}$ and anodic stripping voltammetry (ASV), ${ }^{5}$ have high sensitivity and selectivity but require specialized instrumentation and extensive sample pretreatment processes which limit their applications for in situ analysis. ${ }^{6,7}$

In recent years, much effort has been devoted toward design of DNA-based sensors to detect heavy metal ions, especially $\mathrm{Ag}^{+}, \mathrm{Hg}^{2+}$, and $\mathrm{Pb}^{2+}$, which are three of the most toxic heavy metals. ${ }^{8}$ The detection of $\mathrm{Pb}^{2+}$ relies on the specific catalytic activity of $\mathrm{Pb}^{2+}$ for the particular DNAzyme. For $\mathrm{Pb}^{2+}$ detection, most detectors were based on the $\mathrm{Pb}^{2+}$-dependent DNAzyme $\mathrm{D}^{9,10}$ and $\mathrm{Pb}^{2+}$-stabilized
G-quaduplex. ${ }^{11,12}$ As for $\mathrm{Hg}^{2+}$ and $\mathrm{Ag}^{+}$, the detections relies on the selective capture of $\mathrm{Hg}^{2+}$ by T-T mismatches to form $\mathrm{T}-\mathrm{Hg}$ (II)-T base pairs, ${ }^{13,14}$ and the exclusive recognition of $\mathrm{Ag}^{+}$by C-C mismatches to form C-Ag(I)-C complex. ${ }^{15,16}$ Accordingly, various detection techniques, such as colorimetry, ${ }^{17-19}$ electrochemistry, ${ }^{10,20,21}$ and fluorescence, ${ }^{15,22,23}$ were applied to selectively detect $\mathrm{Pb}^{2+}, \mathrm{Ag}^{+}$, or $\mathrm{Hg}^{2+}$. Given that metal ions usually coexist in several samples, some researches have been focused on the simultaneous detection of two or more metal ions at trace level, such as $\mathrm{Pb}^{2+}$ and $\mathrm{Hg}^{2+},{ }^{24,25}$ as well as $\mathrm{Hg}^{2+}$ and $\mathrm{Ag}^{+}$. ${ }^{26-28}$

However, with regard to the sensors designed for the simultaneous detection of three metal ions, there are only a few relevant reports. Zhang et al. ${ }^{29}$ developed a colorimetric assay for parallel detection of $\mathrm{Cd}^{2+}, \mathrm{Ni}^{2+}$, and $\mathrm{Co}^{2+}$ utilizing peptide modified gold nanoparticles as a sensing element based on its unique surface plasmon resonance properties. Hien et al. ${ }^{30}$ designed a fluorescent chemosensor based on dimethylaminocinnamaldehyde-aminothiourea and applied it for simultaneous detection of $\mathrm{Ag}^{+}, \mathrm{Hg}^{2+}$, and $\mathrm{Pb}^{2+}$. Lin et al. ${ }^{31}$ reported an unlabeled immobilized DNA- 
based sensor for simultaneous detection of $\mathrm{Pb}^{2+}, \mathrm{Ag}^{+}$, and $\mathrm{Hg}^{2+}$ by electrochemical impedance spectroscopy (EIS) with $\left[\mathrm{Fe}(\mathrm{CN})_{6}\right]^{4-/ 3-}$ as redox probe. However, they have some limitations including poor selectivity, insufficient sensitivity, or the need of using the masking reagent.

In this paper, we designed a DNA-based sensor to achieve a rapid, simple and simultaneous detection of $\mathrm{Pb}^{2+}, \mathrm{Ag}^{+}$, and $\mathrm{Hg}^{2+}$ based on the DNA interaction with these metal ions and AuNP fluorescence quenching effect on the fluorescence dyes. Three fluorescence dyes, aminomethylcoumarin acetic acid (AMCA), 5-carboxyfluorescein (FAM), and rhodamine B isothiocyanate (RBITC), were introduced in this assay to detect $\mathrm{Pb}^{2+}, \mathrm{Ag}^{+}$, and $\mathrm{Hg}^{2+}$, respectively. Consequently, no masking reagent was needed in this method so that the detection process was simplified and speeded up. Fluorescence spectra were used at trace level due to its high sensitivity.

\section{Experimental}

\section{1. Materials and Instrumentation}

Reagents including $\mathrm{AgNO}_{3}, \mathrm{Hg}\left(\mathrm{NO}_{3}\right)_{2}, \mathrm{~Pb}\left(\mathrm{NO}_{3}\right)_{2}$, $\mathrm{Ca}\left(\mathrm{NO}_{3}\right)_{2}, \mathrm{Mg}\left(\mathrm{NO}_{3}\right)_{2}, \mathrm{Al}\left(\mathrm{NO}_{3}\right)_{3}, \mathrm{Co}\left(\mathrm{NO}_{3}\right)_{2}, \mathrm{Cu}\left(\mathrm{NO}_{3}\right)_{2}$, $\mathrm{Cr}\left(\mathrm{NO}_{3}\right)_{3}, \mathrm{Zn}\left(\mathrm{NO}_{3}\right)_{2}, \mathrm{Ni}\left(\mathrm{NO}_{3}\right)_{2}, \mathrm{KNO}_{3}, \mathrm{NaNO}_{3}, \mathrm{Cd}\left(\mathrm{NO}_{3}\right)_{2}$, trisodium citrate, $1 \% \mathrm{HAuCl}_{4}, \mathrm{~K}_{2} \mathrm{CO}_{3}$, RBITC, High Performance Liquid Chromatography (HPLC) purified oligonucleotides (aDNA:5'-FAM-ACCCCTC-3', bDNA:5'-ATGTCACTT-3'-SH-, cDNA: 5'-AMCA-AAGTGACA TrAGGACGATCACCCCT-3'-SH-, dDNA:5'- ATCGTCTCCGAGCCGGTCGAAATGTC-3') were purchased from Shanghai Sangon Biotechnology Co., Ltd. Deionized water (18.2 $\mathrm{M} \Omega \mathrm{cm}$ resistivity) from a Millipore Milli-Q system was used throughout this work.

Fluorescence spectra were recorded by F-4600 fluorescence spectrophotometer (Hitachi, Japan) with the excitation and emission slit widths $5.0 \mathrm{~nm}$ and $10.0 \mathrm{~nm}$, voltage $700 \mathrm{~V}$, and excitation and emission wavelengths of 495 $\mathrm{nm}$ and $517 \mathrm{~nm}$ for FAM-ssDNA, $530 \mathrm{~nm}$ and $580 \mathrm{~nm}$ for RBITC, and $353 \mathrm{~nm}$ and $450 \mathrm{~nm}$ for AMCA, respectively.

\section{2. Preparation of Functionalized AuNPs Probe and Analytical Procedure}

cDNA $(5 \mu \mathrm{M})$ and dDNA $(5 \mu \mathrm{M})$ were mixed uniformly, reacting for $5 \mathrm{~min}$ in $90^{\circ} \mathrm{C}$ water bath. Then the mixture was gradually cooled to room temperature to form double-stranded "cDNA+dDNA".

RBITC solution $(1 \mathrm{mM}, 10 \mu \mathrm{L})$ was added into AuNPs suspension ( $13 \mathrm{~nm}, 1 \mathrm{~mL}$ ); the mixture was incubated at room temperature for $2 \mathrm{~h}$, and then centrifuged. The filter cake was added to double-stranded "cDNA+dDNA" solution $(5 \mu \mathrm{M})$ and bDNA solution $(5 \mu \mathrm{M})$, respectively, to synthesize cDNA+dDNA-AuNP and bDNA-AuNP probes. Next, the solution containing cDNA+dDNA-AuNP and bDNA-AuNP probes was mixed uniformly with the same volume of aDNA solution. All the prepared mixtures were stored at $4{ }^{\circ} \mathrm{C}$ for later use.

For $\mathrm{Pb}^{2+}$ sensing, $\mathrm{Pb}^{2+}$ solutions of different concentrations $(10,50,100,300,500,700$ and $1000 \mathrm{nM})$ were prepared and added into the sensor solution prepared as described above, reacting at room temperature for $20 \mathrm{~min}$. The concentration of both $\mathrm{Ag}^{+}$and $\mathrm{Hg}^{2+}$ were $10 \mu \mathrm{M}$ in these solutions. Afterwards, the fluorescence emission spectra were measured at excitation wavelength of $353 \mathrm{~nm}$. For $\mathrm{Ag}^{+}$and $\mathrm{Hg}^{2+}$ detection, similar procedures were followed to those described for $\mathrm{Pb}^{2+}$.

For the selectivity measurement, other metal ions solution $(10 \mu \mathrm{M})$ were added into the sensor solution, and the fluorescence spectra were monitored at excitation wavelengths of $353 \mathrm{~nm}, 495 \mathrm{~nm}$, and $530 \mathrm{~nm}$, respectively.

The real sample was collected from East Lake in Wuhan City and used after being filtered, and the sample was spiked with different concentrations of $\mathrm{Pb}^{2+}, \mathrm{Ag}^{+}$, and $\mathrm{Hg}^{2+}$ to implement the recovery test.

\section{Results and Discussion}

\section{1. Sensing Strategy}

Fig. 1 depicts the process of simultaneous detection. Three fluorescent dyes, AMCA, FAM, and RBITC, served as fluorescent donors for detection of $\mathrm{Pb}^{2+}, \mathrm{Ag}^{+}$, and $\mathrm{Hg}^{2+}$, respectively. The newly synthesized AuNPs were selected as fluorescent receptor owing to their advantages, such as: small particle size, large specific surface area, strong adsorption capacity and excellent water-solubility. RBITC was initially combined with AuNP (recorded as AuNPRBITC), resulting in fluorescence quenching at $580 \mathrm{~nm}$. AMCA was specially designed to label at one end of the substrate strand of 8-17 DNAzyme, and the other end was combined with AuNP, emitting fluorescence signal at 450 nm. FAM was combined with ACCCCTC-3' (aDNA), and this FAM-aDNA fluoresced at $520 \mathrm{~nm}$. In addition, the surfaces of some AuNPs were modified with 5'ATGTCACTT-3'-SH-(bDNA). Then when adding $\mathrm{Pb}^{2+}, \mathrm{Ag}^{+}$, and $\mathrm{Hg}^{2+}$ into the bulk solution, the fluorescence intensity would change due to the interaction between these metal ions and the DNA sequences labeled by fluorescent dye. $\mathrm{Pb}^{2+}$ cleaved the substrate strand of DNAzyme at the ribonucleic adenosine (rA) base, releasing two kinds of DNA fragments: AuNP-cDNA and AMCA-dDNA. dDNA complementarily paired with bDNA-AuNP, to shorten the distance between AMCA and the surface of AuNPs, resulting in fluorescence quenching of AMCA. Simultaneously, $\mathrm{Ag}^{+}$ prompted AuNP-cDNA and aDNA to form a strong double-stranded DNA via the stable "C-Ag+-C" complex, resulting in fluorescence quenching of FAM. There is also a limitation in our sensor that $\mathrm{Ag}^{+}$cannot be detected in the absence of $\mathrm{Pb}^{2+}$. If there is no $\mathrm{Pb}^{2+}$ in the system, a slight amount of $\mathrm{Pb}^{2+}$ should be introduced to trigger the subsequent reactions. 


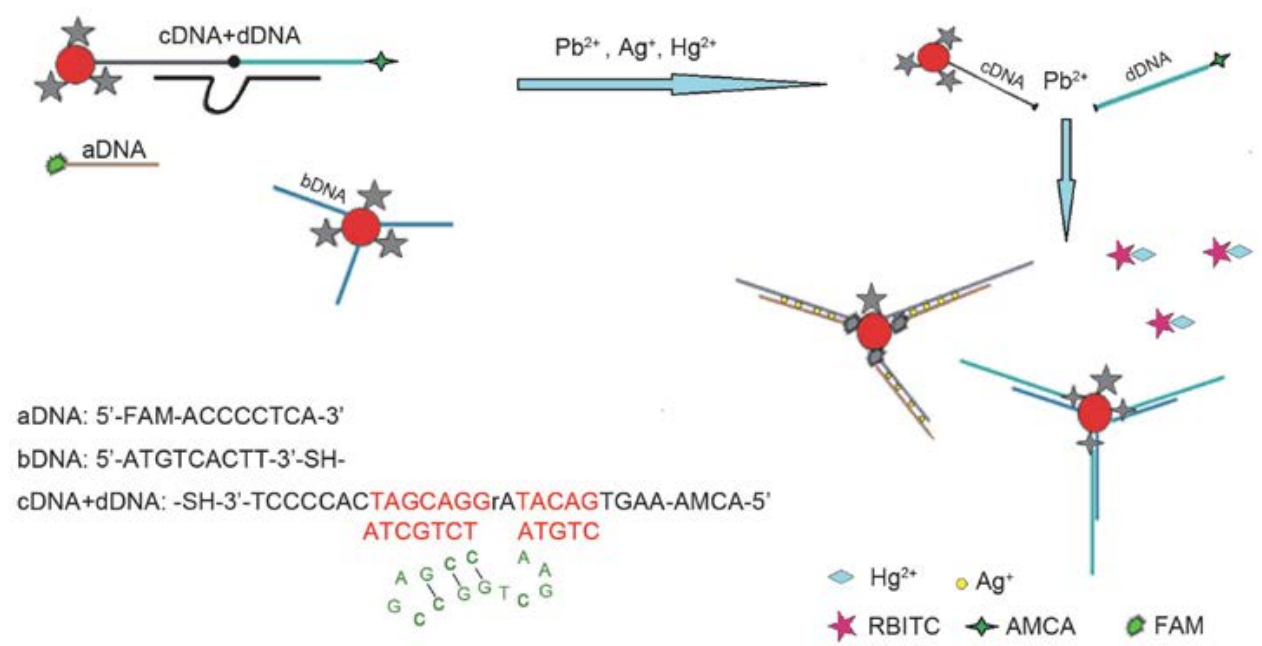

Fig. 1. Schematic of simultaneous detection of $\mathrm{Ag}^{+}, \mathrm{Hg}^{2+}$, and $\mathrm{Pb}^{2+}$ using AuNP-based fluorescent sensors.

As for $\mathrm{Hg}^{2+}$, owing to the larger stability constant of the complex formed by $\mathrm{Hg}^{2+}$ and RBITC than that of the complex formed by AuNPs and RBITC, RBITC would displace from the surface of AuNPs and combine with $\mathrm{Hg}^{2+}$, leading to fluorescence recovery of RBITC.

\section{2. Simultaneous Detection of $\mathbf{P b}^{2+}, \mathbf{A g}^{+}$, and $\mathrm{Hg}^{2+}$}

Fig. 2 shows the fluorescence emission spectra of the AuNP probe solution before and after adding $\mathrm{Pb}^{2+}, \mathrm{Ag}^{+}$, and $\mathrm{Hg}^{2+}$. As illustrated in Fig. 2(A), the presence of $\mathrm{Pb}^{2+}$ in the AuNP-bDNA and AuNP-cDNA+dDNA-AMCA solution leads to $\sim 95 \%$ fluorescence quenching of AMCA (compare Curves 3 with 1 or 2 ), due to the complementary pairing of AuNP-bDNA with the released AMCA-dDNA caused by $\mathrm{Pb}^{2+}$-induced cleavage. In Fig. 2(B), fluorescence of FAM quenched $\sim 70 \%$ with the addition of $\mathrm{Ag}^{+}$ into FAM-aDNA and AuNP-cDNA-dDNA-AMCA (compare Curves 6 with 4 or 5) owing to the $\mathrm{Ag}^{+}$-introduced combination of FAM-aDNA and AuNP-cDNA released after $\mathrm{Pb}^{2+}$-induced cleavage. In Fig. 2(C), the significant fluorescence recovery of RBITC (compare Curves 7 and 8) proves the strong binding of $\mathrm{Hg}^{2+}$ and RBITC, which impelled the RBITC's departing from surface of AuNPs and caused fluorescence recovery.

In Fig.2(A), the coincidence of Curve 1 and 2 shows that fluorescence signal was almost unchanged when AuNPs-bDNA was added into AuNP-cDNA+dDNA-AM$\mathrm{CA}$, indicating $\mathrm{dDNA}$ and bDNA would not pair in the absence of $\mathrm{Pb}^{2+}$, which can guarantee the precision for $\mathrm{Pb}^{2+}$. Similarly, fluorescence signal of FAM remained almost unchanged when aDNA was added into AuNP-cDNA+dDNA-AMCA (compare Curve 4 with 5 ). It is because cDNA part of the DNAzyme substrate strand was specially designed to be rich in an odd number of $C$ bases arranged asymmetrically, so as to avoid the combination of "C- $\mathrm{Ag}^{+}-\mathrm{C}$ " complex by aDNA itself in the presence of $\mathrm{Ag}^{+}$ and improve the precision of detection of $\mathrm{Ag}^{+}$. In order to further ensure the precision of this detection method, we analyzed the mutual impacts among the three metal ions during the detection process. As shown in Fig. 3, the detection results remained unchanged in the presence of all three metal ions or only one of these metal ions, proving
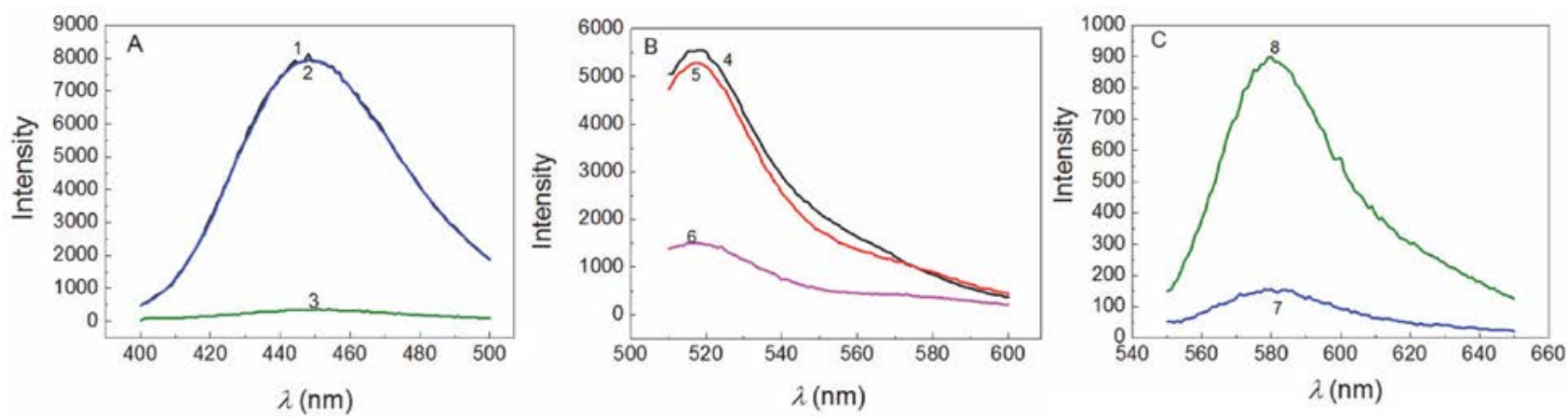

Fig. 2. Fluorescence emission spectra of the detection of (A) $\mathrm{Pb}^{2+}\left(\lambda_{\mathrm{ex}}=353 \mathrm{~nm}, \lambda_{\mathrm{em}}=450 \mathrm{~nm}\right),(\mathrm{B}) \mathrm{Ag}^{+}\left(\lambda_{\mathrm{ex}}=495 \mathrm{~nm}, \lambda_{\mathrm{em}}=517 \mathrm{~nm}\right),(\mathrm{C}) \mathrm{Hg}{ }^{2+}\left(\lambda_{\mathrm{ex}}\right.$ $=530 \mathrm{~nm}, \lambda_{\mathrm{em}}=580 \mathrm{~nm}$ ) in the solution containing (1) AuNP-cDNA-dDNA-AMCA, (2) AuNP-cDNA-dDNA-AMCA + AuNP-bDNA, (3) AuNP-cDNA-dDNA-AMCA + AuNP-bDNA + $\mathrm{Pb}^{2+}$, (4) FAM-aDNA, (5) FAM-aDNA + AuNP-cDNA, (6) FAM-aDNA + AuNP-cDNA + Ag , $^{+}$(7) AuNP-RBITC, (8) AuNP-RBITC $+\mathrm{Hg}^{2+}$. 


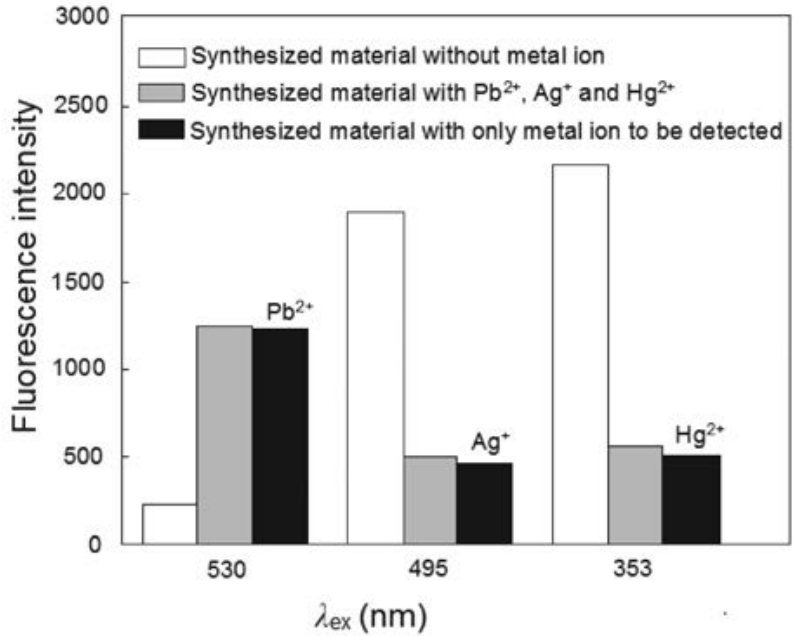

Fig. 3. Mutual impacts among the three metal ions during the detection process. that the detection of these three metal ions was independent from each other.

Furthermore, fluorescence intensity changes rapidly in response to the addition of the metal ions. As shown in Fig. 4, the reactions reached equilibrium after about $600 \mathrm{~s}$ for $\mathrm{Pb}^{2+}, 200 \mathrm{~s}$ for $\mathrm{Ag}^{+}$, and $200 \mathrm{~s}$ for $\mathrm{Hg}^{2+}$. The results indicated that this sensor allows a rapid detection of three heavy metal ions with high stability.

\section{3. Sensitivity and Selectivity of Simultaneous Detection for $\mathrm{Pb}^{2+}, \mathrm{Ag}^{+}$, and $\mathrm{Hg}^{2+}$}

In order to evaluate the sensitivity of the sensor for $\mathrm{Pb}^{2+}, \mathrm{Ag}^{+}$, and $\mathrm{Hg}^{2+}$, different concentrations of these metal ions were added into the sensor solution under the optimized conditions such as $\mathrm{pH}=8.0$, RBITC concentration is $1 \mathrm{mM}$ and DNA concentration is $5 \mu \mathrm{M}$.
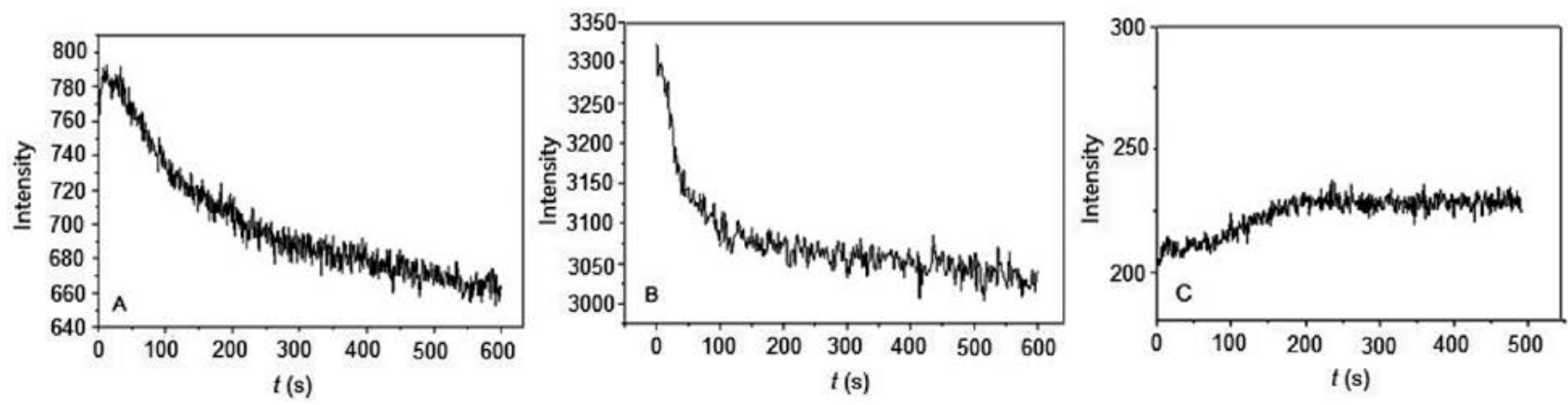

Fig. 4. Fluorescence intensity changes vs. time after adding (A) $\mathrm{Pb}^{2+}$, (B) $\mathrm{Ag}^{+}$, and (C) $\mathrm{Hg}^{2+}$.
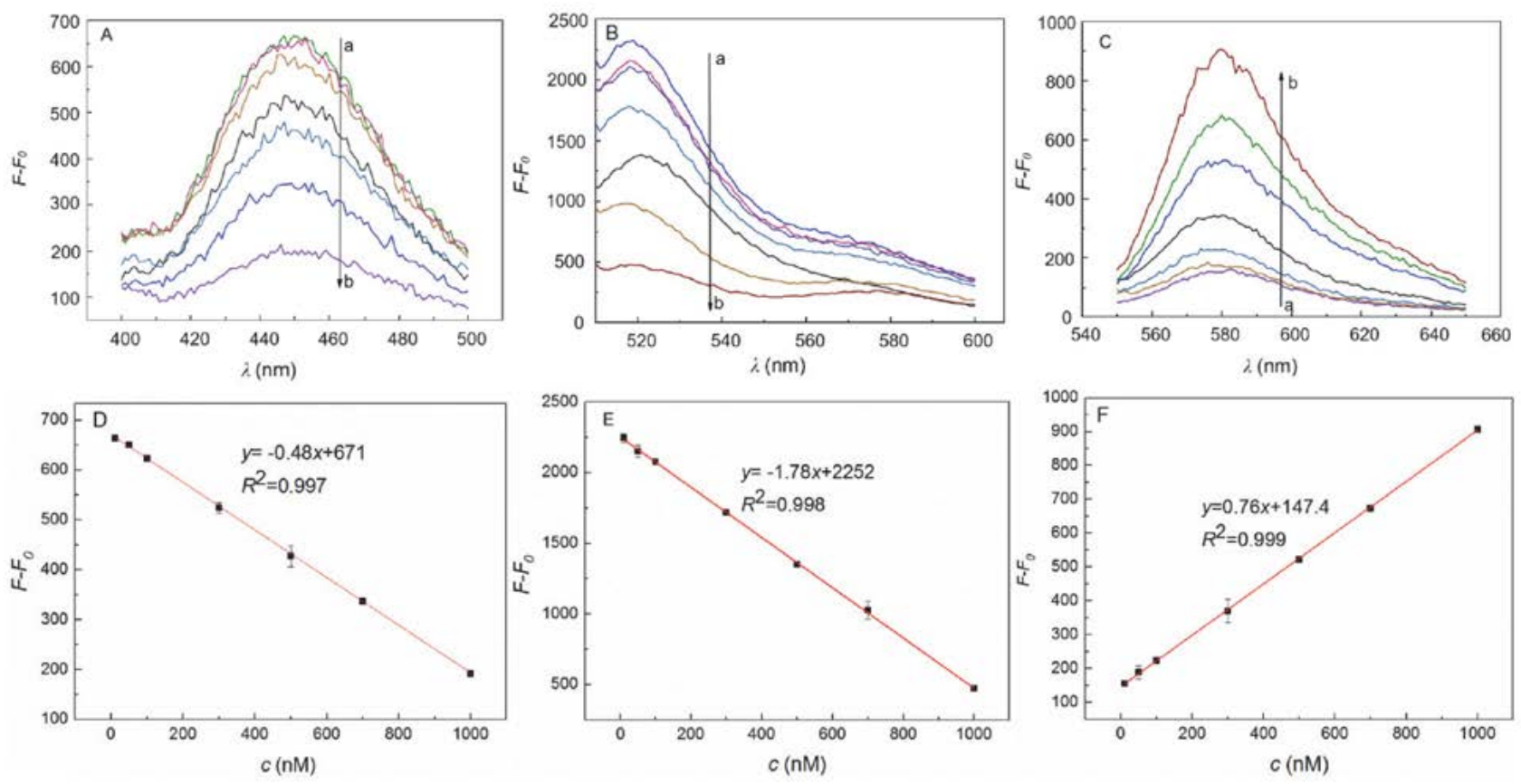

Figure 5. Fluorescence emission spectra of (A) $\mathrm{Pb}^{2+}\left(\lambda_{\mathrm{ex}}=353 \mathrm{~nm}, \lambda_{\mathrm{em}}=450 \mathrm{~nm}\right),(\mathrm{B}) \mathrm{Ag}^{+}\left(\lambda_{\mathrm{ex}}=495 \mathrm{~nm}, \lambda_{\mathrm{em}}=517 \mathrm{~nm}\right)$, and $(\mathrm{C}) \mathrm{Hg}^{2+}\left(\lambda_{\mathrm{ex}}=530\right.$ $\mathrm{nm}, \lambda_{\mathrm{em}}=580 \mathrm{~nm}$ ), and standard curves of (D) $\mathrm{Pb}^{2+}$, (E) $\mathrm{Ag}^{+}$, and (F) $\mathrm{Hg}^{2+}$ in the concentration of (a $\left.\sim \mathrm{b}\right) 10,50,100,300,500,700,1000 \mathrm{nM}$. F is measured fluorescence intensity, $F_{0}$ is background fluorescence intensity. 
As shown in Fig. 5, the fluorescence spectra changed regularly. The intensity of AMCA $\left(\lambda_{\mathrm{ex}}=353 \mathrm{~nm}, \lambda_{\mathrm{em}}=450\right.$ $\mathrm{nm})$ and FAM $\left(\lambda_{\mathrm{ex}}=495 \mathrm{~nm}, \lambda_{\mathrm{em}}=517 \mathrm{~nm}\right)$ gradually decreased with increased concentration of $\mathrm{Pb}^{2+}$ and $\mathrm{Ag}^{+}$, respectively; while the intensity of RBITC ( $\lambda_{\text {ex }}=530 \mathrm{~nm}, \lambda_{\text {em }}$ $=580 \mathrm{~nm}$ ) increased with the increased concentration of $\mathrm{Hg}^{2+}$, which proved the fluorescence quenching caused by $\mathrm{Pb}^{2+}$ and $\mathrm{Ag}^{+}$, and the fluorescence recovery caused by $\mathrm{Hg}^{2+}$. The LOD (limit of detection) of this assay was $0.48 \mathrm{nM}, 0.23$ $\mathrm{nM}$ and $0.17 \mathrm{nM}$ for $\mathrm{Pb}^{2+}, \mathrm{Ag}^{+}$, and $\mathrm{Hg}^{2+}$, respectively. The linear range was $10 \mathrm{nM} 1000 \mathrm{nM}$ for the three ions.

The selectivity of the sensing system was also explored: the fluorescence spectra were monitored upon adding other metal ions (such as $10 \mu \mathrm{M} \mathrm{Mg}^{2+}, \mathrm{Ca}^{2+}, \mathrm{Fe}^{3+}, \mathrm{Co}^{2+}$, $\left.\mathrm{Ni}^{2+}, \mathrm{Zn}^{2+}, \mathrm{Cd}^{2+}, \mathrm{Al}^{3+}, \mathrm{Cr}^{3+}, \mathrm{Cu}^{2+}\right)$ to the sensing system in the presence of $1 \mu \mathrm{M} \mathrm{Ag}^{+}, \mathrm{Hg}^{2+}$, and $\mathrm{Pb}^{2+}$. As shown in Fig. 5, Only $\mathrm{Pb}^{2+}, \mathrm{Ag}^{+}$, and $\mathrm{Hg}^{2+}$ caused considerable changes in the intensity of fluorescent signals while other ions have little effect on this system. These results illustrated that the sensor was specifically responding to the three metal ions.

The comparison of the proposed sensor with other methods for simultaneous determination of three metal ions is listed in Table 1. As it can be seen, the proposed sensor has a comparable and even higher sensitivity to the previous reports, and no masking reagent was used in this method, indicating that this sensor was an appropriate platform for the determination of these metal ions.

\section{4. Detection of $\mathrm{Pb}^{2+}, \mathrm{Hg}^{2+}$, and $\mathrm{Ag}^{+}$in Real Samples}

This sensor's application in real samples (water of the East Lake) were investigated by Standard Recovery Test. the sample of the East Lake water was filtered through a $0.45 \mu \mathrm{m}$ cellulose acetate filter membrane, and then the water sample $(10 \mu \mathrm{L})$ was added to the prepared sensor. Afterwards, the standard solution of three metal ions was added to reach the final concentration of $10 \mathrm{nM}$. The fluorescence intensities were detected at $450 \mathrm{~nm}, 580$ $\mathrm{nm}$ and $517 \mathrm{~nm}$. The fluorescent quenching responding to $\mathrm{Pb}^{2+}$ and $\mathrm{Ag}^{+}$, and recovery responding to $\mathrm{Hg}^{2+}$ were also observed in East Lake water (as indicated in Fig. 7), and Table 2 shows that the satisfactory recoveries were obtained for the real samples. The average recoveries are
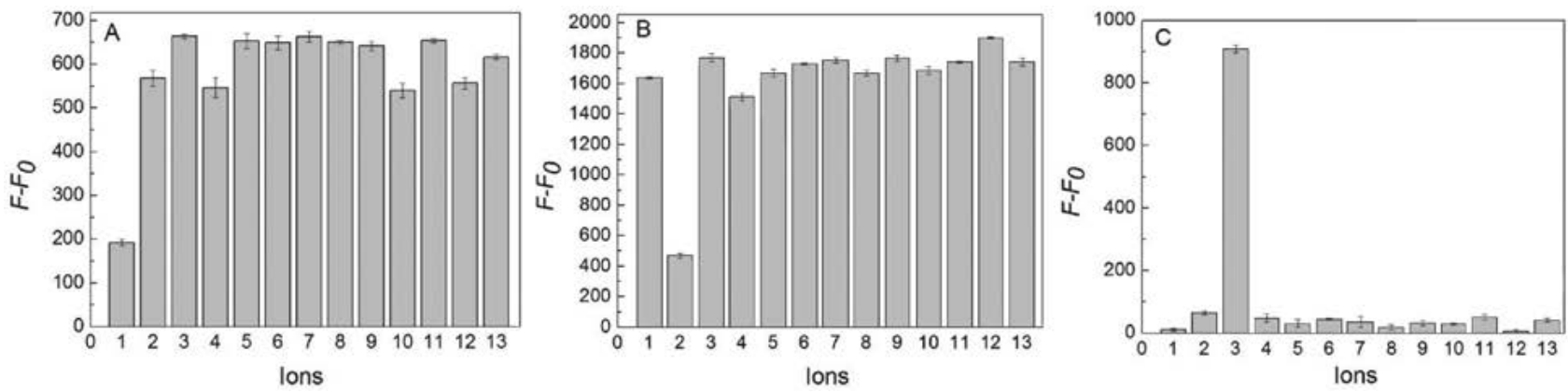

Figure 6. Selective detection of three metal ions at (A) $\lambda_{\mathrm{ex}}=353 \mathrm{~nm}, \lambda_{\mathrm{em}}=450 \mathrm{~nm}$; (B) $\lambda_{\mathrm{ex}}=495 \mathrm{~nm}, \lambda_{\mathrm{em}}=517 \mathrm{~nm}$; (C) $\lambda_{\mathrm{ex}}=530 \mathrm{~nm}, \lambda_{\mathrm{em}}=580 \mathrm{~nm}$. 1-13: $\mathrm{Pb}^{2+}, \mathrm{Ag}^{+}, \mathrm{Hg}^{2+}, \mathrm{Mg}^{2+}, \mathrm{Ca}^{2+}, \mathrm{Fe}^{3+}, \mathrm{Co}^{2+}, \mathrm{Ni}^{2+}, \mathrm{Zn}^{2+}, \mathrm{Cd}^{2+}, \mathrm{Al}^{3+}, \mathrm{Cr}^{3+}, \mathrm{Cu}^{2+}$. The concentrations of $\mathrm{Pb}^{2+}, \mathrm{Ag}^{+}, \mathrm{Hg}^{2+}$ to be measured were $1 \mu \mathrm{M}$, and the concentrations of other metal ions were $10 \mu \mathrm{M}$. $F$ is measured fluorescence intensity, $F_{0}$ is background fluorescence intensity.

Table 1. The comparison of our sensor with other methods for simultaneous determination of three metal ions.

\begin{tabular}{llll}
\hline Method & $\begin{array}{l}\text { Ions detected } \\
\text { and its LOD }\end{array}$ & $\begin{array}{c}\text { Using masking } \\
\text { reagent }\end{array}$ & Ref. \\
\hline $\begin{array}{l}\text { peptide modified } \\
\text { gold nanoparticles } \\
\text { probe }\end{array}$ & $\begin{array}{l}\mathrm{Cd}^{2+}(0.05 \mathrm{mM}) \\
\mathrm{Ni}^{2+}(0.3 \mathrm{mM}) \\
\mathrm{Co}^{2+}(2 \mathrm{mM})\end{array}$ & $\mathrm{Y}$ & {$[29]$} \\
\hline $\begin{array}{l}\text { fluorescent chemosensor based on } \\
\text { dimethylaminocinnamaldehyde- }\end{array}$ & $\begin{array}{l}\mathrm{Ag}^{+}(1.0 \mathrm{ppb}) \\
\mathrm{Hg}^{2+}(2.8 \mathrm{ppb})\end{array}$ & $\mathrm{Y}$ & \\
aminothiourea & $\mathrm{Cu}^{2+}(0.8 \mathrm{ppb})$ & & \\
\hline & $\mathrm{Ag}^{+}(10 \mathrm{nM})$ & \\
DNA-based sensor & $\mathrm{Hg}^{2+}(0.1 \mathrm{nM})$ & $\mathrm{Y}$ & \\
& $\mathrm{Pb}^{2+}(10 \mathrm{pM})$ & & \\
\hline & $\begin{array}{l}\mathrm{Ag}^{+}(0.23 \mathrm{nM}) \\
\mathrm{Hg}^{2+}(0.17 \mathrm{nM})\end{array}$ & $\mathrm{N}$ \\
$\mathrm{Pb}^{2+}(0.48 \mathrm{nM})$ & & Our method \\
\hline
\end{tabular}



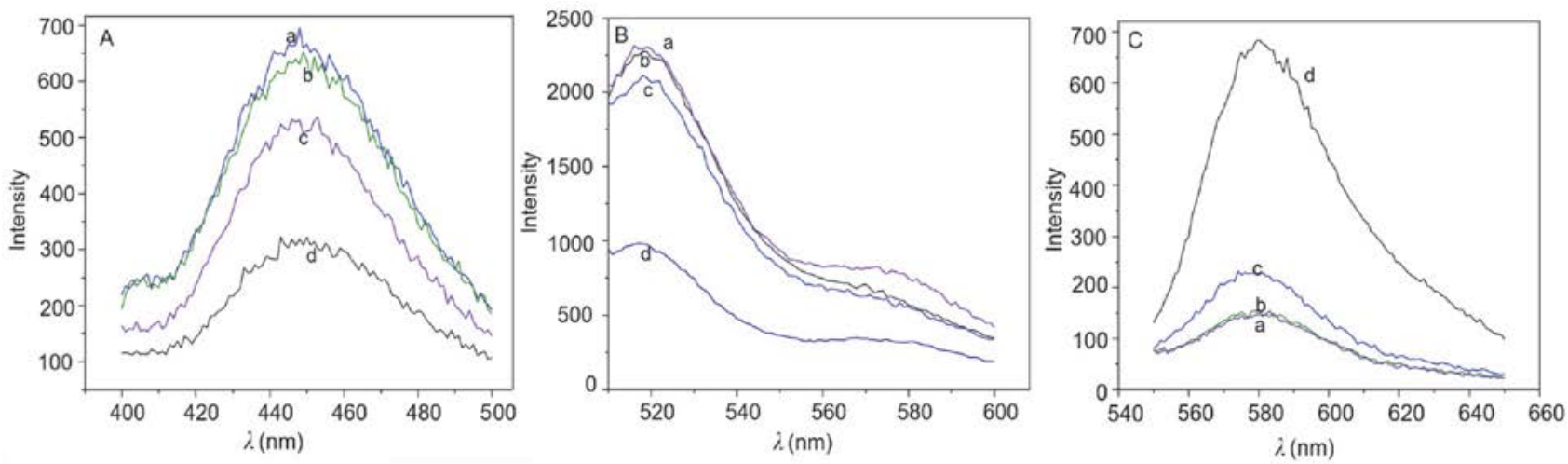

Figure 7. Fluorescence curves of (A) $\mathrm{Pb}^{2+}$ (with added standard concentration of (a) 0, (b) $50 \mathrm{nM}$, (c) $300 \mathrm{nM}$, and (d) $700 \mathrm{nM}$ ), (B) $\mathrm{Ag}^{+}$(with added standard concentration of (a) 0, (b) $10 \mathrm{nM}$ (c) $100 \mathrm{nM}$, and (d) $700 \mathrm{nM}$ ), and (C) $\mathrm{Hg}^{2+}$ (with added standard concentration of (a) 0 , (b) $10 \mathrm{nM}$ (c) $100 \mathrm{nM}$, and (d) $700 \mathrm{nM}$ ) in East Lake water.

Table 2. Standard Recovery Test for detection of the metal ions in East Lake water.

\begin{tabular}{|c|c|c|c|c|c|}
\hline Metal ions & Sample & $\begin{array}{l}\text { Measured concentration } \\
\text { in test sample / } \mathbf{n M}\end{array}$ & $\begin{array}{c}\text { Added standard } \\
\text { concentrations } / \mathbf{n M}\end{array}$ & $\begin{array}{l}\text { Measured concentration after } \\
\text { adding standard } \\
\text { concentrations / } \mathbf{n M}\end{array}$ & $\begin{array}{c}\text { Recovery } \\
/ \%\end{array}$ \\
\hline \multirow{4}{*}{$\mathrm{Pb}^{2+}$} & 1 & 9.79 & 50 & 67.71 & 115.8 \\
\hline & 2 & 9.79 & 300 & 331.04 & 107.1 \\
\hline & 3 & 9.79 & 700 & 726.46 & 102.4 \\
\hline & 1 & 1.12 & 10 & 12.36 & 112.4 \\
\hline \multirow[t]{3}{*}{$\mathrm{Ag}^{+}$} & 2 & 1.12 & 100 & 105.62 & 104.5 \\
\hline & 3 & 1.12 & 700 & 719.72 & 102.7 \\
\hline & 1 & 1.45 & 10 & 11.32 & 98.7 \\
\hline \multirow[t]{2}{*}{$\mathrm{Hg}^{2+}$} & 2 & 1.45 & 100 & 105.39 & 103.9 \\
\hline & 3 & 1.45 & 700 & 707.76 & 100.9 \\
\hline
\end{tabular}

$108.43 \%$ for $\mathrm{Pb}^{2+}, 106.53 \%$ for $\mathrm{Ag}^{+}$and $101.17 \%$ for $\mathrm{Hg}^{2+}$. These results confirmed that the proposed sensor can be successfully used to detect $\mathrm{Pb}^{2+}, \mathrm{Ag}^{+}$, and $\mathrm{Hg}^{2+}$ in real samples.

\section{Conclusions}

In this paper, we have described a successful design of a new and simple fluorescent sensor for simultaneous detection of $\mathrm{Pb}^{2+}, \mathrm{Ag}^{+}$, and $\mathrm{Hg}^{2+}$ based on the specific catalytic activity of $\mathrm{Pb}^{2+}$ for a particular DNAzyme, specific regulation of $\mathrm{Ag}^{+}$on "C- $\mathrm{Ag}^{+}-\mathrm{C}$ " complex, stable complex formed by $\mathrm{Hg}^{2+}$ and RBITC, and AuNP fluorescence quenching effect on fluorescence dyes. Fluorescence quenching of AMCA and FAM, and the fluorescence recovery of RBITC indicated the presence of $\mathrm{Pb}^{2+}$, $\mathrm{Ag}^{+}$, and $\mathrm{Hg}^{2+}$, and the intensity changed corresponding to concentration of these ions. The detection limits of three metal ions were $0.48 \mathrm{nM}$ for $\mathrm{Pb}^{2+}, 0.23 \mathrm{nM}$ for $\mathrm{Ag}^{+}$

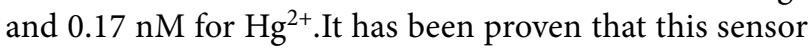
is characterized by good stability, high sensitivity and selectivity, fast detection speed, and easy operation, and has successfully produced satisfactory detection results in real samples. These attributions suggest that our approach provides a well suitable method to simultaneous detection of a variety of heavy metal ions in environmental monitoring.

\section{Acknowledgements}

This work is supported by the National Natural Science Foundation of China (NSFC) (Grant No. 41273093, 81471696) and the Project of Experimental technology of Wuhan University (Grant No. WHU-2014-SYJS-09). Financial support from the Fundamental Research Funds for the Central Universities is acknowledged.

\section{References}

1. G. C. Zhu and C. Y. Zhang, Analyst 2014, 139, 6326-6342. DOI:10.1039/C4AN01069H

2. T. Li, E. K. Wang, S. J. Dong, Chem. Commun. 2009, 5, 580582. DOI:10.1039/B815814B

3. Y. Miyake, H. Togashi, M. Tashiro, H. Yamaguchi, S. Oda, M. Kudo, Y. Tanaka, Y. Kondo, R. Sawa, T. Fujimoto, T. Machinami, A. Ono, J. Am. Chem. Soc. 2006, 128, 2172-2173.

DOI:10.1021/ja056354d 
4. A. Ataro, R. I. McCrindle, B. M. Botha, C. M. E. McCrindle, P. P. Ndibewu, Food Chem. 2008, 111, 243-248. DOI:10.1016/j.foodchem.2008.03.056

5. D. W. Pan, Y. E. Wang, Z. P. Chen, T. T. Lou, W. Qin, Anal. Chem. 2009, 81, 5088. DOI:10.1021/ac900417e

6. S. J. Lee, M. Moskovits, Nano Lett. 2011, 11, 145-150. DOI:10.1021/nl1031309

7. Y. X. Du, R. Y. Liu, B. H. Liu, S. H. Wang, M. Y. Han, Z. P. Zhang, Anal. Chem. 2013, 85, 3160-3165.

DOI:10.1021/ac303358w

8. A. Sett, S. Das, U. Bora, Biochem. Biotechnol. 2014, 174, 10731091. DOI:10.1007/s12010-014-0990-3

9. J. Li, Y. Lu, J. Am. Chem. Soc. 2000, 122, 10466-10467. DOI: $10.1021 / \mathrm{ja} 0021316$

10. Y. Xiao, A. A. Rowe, K. W. Plaxco, J. Am. Chem. Soc. 2007, 129, 262-263. DOI:10.1021/ja067278x

11. T. Li, S. J. Dong, E. K. Wang, J. Am. Chem. Soc. 2010, 132, 13156-13157. DOI:10.1021/ja105849m

12. T. Li, E.K. Wang, S.J. Dong, Anal. Chem. 2010, 82, 1515-1520. DOI:10.1021/ac902638v

13. Y. Tanaka, S. Oda, H. Yamaguchi, Y. Kondo, C. Kojima, A. Ono, J. Am. Chem. Soc. 2007, 129, 244-245.

DOI:10.1021/ja065552h

14. Y. Miyake, H. Togashi, M. Tashiro, H. Yamaguchi, S. Oda, M. Kudo, Y. Tanaka, Y. Kondo, R. Sawa, T. Fujimoto, T. Machinami, A. Ono, J. Am. Chem. Soc. 2006, 128, 2172-2173.

DOI:10.1021/ja056354d

15. A. Ono, S. Cao, H. Togashi, M. Tashiro, T. Fujimoto, T. Machinami, S. Oda, Y. Miyake, I. Okamoto, Y. Tanaka, Chem. Commun. 2008, 39, 4825-4827. DOI:10.1039/b808686a

16. H. Torigoe, Y. Miyakawa, N. Nagasawa, T. Kozasa, A. Ono, Nucleic. Acids. Symp. Ser. 2006, 50, 225-226.

DOI:10.1093/nass/nrl112
17. B. Rajam, P. Ramasamy, U. Mahalingam, Acta Chim. Slov. 2017, 64, 186-192. DOI:10.17344/acsi.2016.3054

18. T. Li, S.J. Dong, E. K. Wang, Anal. Chem. 2009, 81, 2144-2149. DOI:10.1021/ac900188y

19. J. J. Du, L. Jiang, Q. Shao, X. G. Liu, R. S. Marks, J. Ma, X. D. Chen, Small 2013, 9, 1467-1481.

DOI:10.1002/smll.201200811

20. M. B. Gumpu, S. Sethuraman, U. M. Krishnan, J. B. B. Rayappan, Sensor Actuat B-Chem. 2015, 213, 515-533.

DOI:10.1016/j.snb.2015.02.122

21. G. Mor-Piperberg, R. Tel-Vered, J. Elbaz, I. Willner, J. Am. Chem. Soc. 2010, 132, 6878-6879. DOI:10.1021/ja1006355

22. J. W. Liu, Anal. Chem. 2014, 58, 99-111.

23. A. Ceylan, S. Z. Bas, M. Bayrakcl, S. Ertul, A. Uysal, Acta Chim. Slov. 2012, 59, 656-663

24. X. L. Shi, X. Y. Gao, L. L. Zhang, Y. C. Li, Analyst 2015, 140, 2608-2612. DOI:10.1039/C5AN00120J

25. S. J. Wu, N. Duan, Z. Shi, C. C. Fang, Z. P. Wang, Talanta 2014, 128, 327-336. DOI:10.1016/j.talanta.2014.04.056

26. C. Y. Lin, C. J. Yu, Y. H. Lin, W. L. Tseng, Anal. Chem. 2010, 82, 6830-6837. DOI:10.1021/ac1007909

27. G. C. Zhu, Y. Li and C. Y. Zhang, Chem. Commun. 2014, 50, 572-574. DOI:10.1039/C3CC46884D

28. Y. R. Chen, K. Mao, X. D. Zhou, A. G. Shen, J. M. Hu, Wuhan University Journal of Natural Sciences 2016, 21, 499-504. DOI:10.1007/s11859-016-1202-5

29. M. Zhang, Y. Q. Liu, B. C. Ye, Analyst 2012, 137, 601-607. DOI:10.1039/C1AN15909G

30. N. K. Hien, N. C. Bao, N. T. A. Nhung, N. T. Trung, P. C. Nam, T. Duong, J. S. Kim, D. T. Quang, Dyes and Pigments 2015, 116, 89-96. DOI:10.1016/j.dyepig.2015.01.014

31. Z. Z. Lin, X. H. Li, H. B. Kraatz, Anal. Chem. 2011, 83, 68966901. DOI:10.1021/ac2014096

\section{Povzetek}

Poročamo o novem fluorescenčnem senzorju na osnovi nukleinskih kislin za simultano detekcijo $\mathrm{Pb}^{2+}, \mathrm{Ag}^{+}$in $\mathrm{Hg}^{2+}$ ionov. Osnovan je na specifični katalitski aktivnosti $\mathrm{Pb}^{2+}$ ionov za določen DNA encim; na specifični regulaciji $\mathrm{Ag}^{+}$na »C- $\mathrm{Ag}^{+}-\mathrm{C}$ « kompleksu; na stabilnem kompleksu, ki ga tvorita $\mathrm{Hg}^{2+}$ in rodamin B izotiocianat (RBITC). Tri fluorescenčna barvila: aminometilkumarin ocetna kislina (AMCA), 5-karboksifluorescein (FAM) in RBITC, smo dodali raztopinam in so služila kot donorji fluorescence. Zaradi interakcije DNA s temi kovinskimi ioni in efekta dušenja fluorescence, ki so ga imeli AuNP delci na fluorescenčna barvila, smo lahko spremljali povečanje fluorescence RBITC za detekcijo $\mathrm{Hg}^{2+}$ ter dušenje fluorescence pri AMCA in FAM za ločeno detekcijo $\mathrm{Pb}^{2+}$ in $\mathrm{Ag}^{+}$, ne da bi bilo treba uporabljati maskirne reagente. Senzor je pokazal visoko občutljivost in selektivnost. Meja zaznave (LOD) je $0,48 \mathrm{nM} \mathrm{za} \mathrm{Pb}^{2+}, 0,23 \mathrm{nM} \mathrm{za} \mathrm{Ag}^{+}$in $0,17 \mathrm{nM} \mathrm{za} \mathrm{Hg}^{2+}$. Na koncu smo senzor uspešno uporabili za hkratno detekcijo $\mathrm{Pb}^{2+}, \mathrm{Ag}^{+}$in $\mathrm{Hg}^{2+}$ ionov v realnem vzorcu. 